\title{
Screening of sugar beet pre-breeding populations and breeding lines for resistance to Ditylenchus dipsaci penetration and reproduction
}

\author{
Alan Storelli ${ }^{1}$ - Alexandra Minder ${ }^{1} \cdot$ Andreas Keiser $^{1} \cdot$ Sebastian Kiewnick $^{2} \cdot$ Matthias Daub $^{2}$. \\ Anne-Katrin Mahlein ${ }^{3} \cdot$ Mario Schumann ${ }^{4} \cdot$ Werner Beyer $^{4}$
}

Received: 20 December 2020 / Accepted: 21 May 2021 / Published online: 30 May 2021

(c) The Author(s) 2021

\begin{abstract}
Ditylenchus dipsaci is an economically important plant-parasitic nematode affecting European sugar beets. To date, no sugar beet cultivars carrying resistance against $D$. dipsaci are available to farmers. To find potentially resistant sugar beet lines restricting reproduction and penetration of $D$. dipsaci, three consecutive in vivo bioassays were carried out. The first experiment determined the penetration rate of $D$. dipsaci in 79 breeding lines and 14 pre-breeding populations. Based on these results, $D$. dipsaci penetration and reproduction resistance of eight genotypes was intensively investigated. It could be demonstrated that none of the genotypes showed resistance towards $D$. dipsaci. However, a high variation of the penetration rate by $D$. dipsaci was observed among the genotypes. The breeding line 'DIT_119' effectively reduced $D$. dipsaci penetration (34.4 \pm 8.8 nematodes/plant at 22 days post-planting) compared to the susceptible control (109.0 \pm 16.9$)$ while ensuring a yield comparable to non-inoculated plants. However, the breeding line 'DIT_119' did not reduce $D$. dipsaci reproduction. The paternal line of the cultivar BERETTA KWS, demonstrating a high tolerance to $D$. dipsaci crown rot symptoms, did not reduce penetration and reproduction. Thus, no correlation can be established between reduced penetration rates, reproduction, and tolerance to $D$. dipsaci. This study provides an essential basis for the development of resistant sugar beet cultivars to $D$. dipsaci. The variations observed among genotypes now need to be confirmed with larger-scale screenings.
\end{abstract}

Keywords Breeding line $\cdot$ In vivo $\cdot$ Penetration $\cdot$ Pre-breeding population $\cdot$ Reproduction $\cdot$ Resistance breeding

\section{Introduction}

The stem and bulb nematode Ditylenchus dipsaci (Kühn 1857) Filipjev 1936 is a migratory endoparasite affecting up to 450 plant species worldwide (Duncan and Moens 2013; Seinhorst 1956). This nematode pest has emerged as an economically threatening plant-parasitic nematode in the

Alan Storelli

alan.storelli@bfh.ch

1 School of Agricultural, Forest and Food Sciences HAFL, Bern University of Applied Sciences BFH, Länggasse 85, 3052 Zollikofen, Switzerland

2 Federal Research Center for Cultivated Plants, Julius Kuehn Institute for Plant Protection in Field Crops and Grassland, Messeweg 11/12, 38104 Braunschweig, Germany

3 Institute of Sugar Beet Research IfZ, Holtenser Landstrasse 77, 37079 Gottingen, Germany

4 KWS SAAT SE \& Co. KGaA, Grimsehlstrasse 31, 37574 Einbeck, Germany
European sugar beet (Beta vulgaris L.) production (Dewar and Cook 2006; Leipertz 2007; Subbotin et al. 2005). The penetration early in the growing season leads to swollen hypocotyls and distorted leaves and cotyledons (Griffin 1983). Later in the season, bacterial and fungal infection, such as Rhizoctonia solani (AG 2-2IIIB) and Verticillium albo-atrum, introduced by $D$. dipsaci leads to the crown's rotting (Hillnhütter et al. 2011; Vrain 1987). Since the withdrawal of the nematicide aldicarb, no effective direct management has been available for control of $D$. dipsaci. The broad range of host plants of $D$. dipsaci hinders crop rotation strategies for successful management of this nematode (Jones et al. 2013). The fungicide fluopyram, a succinate dehydrogenase inhibitor (SDHI), effectively reduced the fungal and bacterial infection introduced by the stem and bulb nematode (Storelli et al. 2020). However, no long-term effect on $D$. dipsaci population development was observed. Therefore, breeding for sugar beet cultivars' resistance is a sustainable management approach (Schomaker and Been 2013). Roberts (2002) described resistance as the plant's ability 
to suppress the development and consequently the reproduction of nematodes. The latter author further described tolerance as the plant's ability to compensate for nematode infection with little or no yield loss. To date, no sugar beet cultivar with resistance against $D$. dipsaci is although available. Kühnhold (2011) observed variations in $D$. dipsaci penetration and reproduction rates depending on the breeding line or cultivar tested. However, D. dipsaci penetration and reproduction rates in less susceptible genotypes were still high (Kühnhold 2011). Some sugar beet cultivars are tolerant to the fungal and bacterial infection introduced by D. dipsaci in the field (Leipertz and Valder 2020). Resistance towards $D$. dipsaci penetration may prevent nematode penetration and, consequently, the introduction of fungal and bacterial pathogens. However, resistance towards D. dipsaci reproduction may reduce nematode population development but does not avoid introducing fungal and bacterial pathogens. Monogenic or polygenic resistance towards the sugar beet cyst nematode Heterodera schachtii (Schmidt) is identified since a long time (Blok et al. 2018; Golden 1959; Savitsky 1975). Resistance towards D. dipsaci has been observed in clover (Trifolium spp.), lucerne (Medicago sativa L.), faba bean (V. fabaea L.), and oat (Avena spp.) cultivars (McDaniel and Barr 1994; Stanton et al. 1984; Starr et al. 2013). Ditylenchus dipsaci resistance is monogenic on lucerne, and polygenic on faba bean, wild oat ( $A$. ludoviciana L.), and red clover (T. pratense L.) (Plowright et al. 2002). Resistant oat cultivars successfully reduced the reproduction of $D$. dipsaci but not the penetration of this nematode pest (Blake 1962; Griffiths et al. 1957). Plowright et al. (2002) reported high resistance against $D$. dipsaci in a faba bean line, which has been used to develop resistant cultivars for North Africa. Despite variations in the nematode reproduction rate among onion (Allium cepa L.) cultivars, Yavuzaslanoglu (2019) found no resistance towards D. dipsaci. Caubel et al. (1994) demonstrated a positive relationship between symptom expression at 3 weeks postinoculation and $D$. dipsaci reproduction at 10 weeks postinoculation on red clover. Cook and Evans (1988) reported no correlation between leaf size of white clover (T. repens L.) and tolerance towards $D$. dipsaci infection. The development of forage crops resistant to $D$. dipsaci was based on the characterization of symptoms on seedlings (Caubel et al. 1994). Variations in the resistance levels of lucerne species depending on the $D$. dipsaci population used were observed (Leclerq and Caubel 1991; Whitehead 1992). The resistance of a host plant to $D$. dipsaci is highly dependent on the geographic origin of the nematode population, which hinders any breeding programme. Our study aims were to identify among 14 pre-breeding populations and 79 breeding lines sugar beets with resistance towards $D$. dipsaci penetration and reproduction. A screening of a wide range of genotypes was first conducted to identify potential candidates for resistance towards $D$. dipsaci penetration. Based on this screening, a more in-depth investigation of the genotypes with potential resistance was conducted to determine their potential resistance to $D$. dipsaci penetration and reproduction. The tolerance of the sugar beet genotypes to $D$. dipsaci infection is determined by assessing plant survival and yield.

\section{Materials and methods}

\section{Nematode inoculum}

The D. dipsaci population used in all experiments was derived from three infested sugar beets tubers (cv. SAMUELA KWS) collected in the Seeland region (CH) in 2015 (47.058154, 7.275107). Nematodes were extracted by Oostenbrink dishes (European and Mediterranean Plant Protection Organization 2013). Fourth-stage juveniles (J4) and adult nematode stages were hand-picked after morphological identification of the tail, median bulb, stylet, and lip shape using an optical microscope at 40x magnification. After suspending the nematodes in an antibiotic solution containing $0.1 \%$ streptomycin sulphate $(\mathrm{w} / \mathrm{v})$ and $0.1 \%$ amphotericin-B $(\mathrm{w} / \mathrm{v})$ for $30 \mathrm{~min}, 50$ nematodes were inoculated per surface sterilized $(1 \% \mathrm{NaOCl})$ carrot disc $(2.5 \times 5 \mathrm{~cm})$ and incubated for 45 days at $20^{\circ} \mathrm{C}$ in the dark (Kühnhold et al. 2006; Storelli et al. 2021). The nematodes were extracted from the carrot discs, stored in the dark at $6-8{ }^{\circ} \mathrm{C}$, and after $24 \mathrm{hr}$ the sugar beet plants were inoculated. On average, D. dipsaci suspensions used for inoculation contained $43 \pm 1.5 \%$ eggs, $28 \pm 0 \%$ second- and third-stage juveniles (J2-3), and $29 \pm$ $1.5 \%$ of $\mathrm{J} 4 \mathrm{~s}$ and adult stages.

\section{Plant material}

Investigated plant material included 79 breeding lines and 14 pre-breeding populations from the KWS gene pool (KWS SAAT SE \& Co. KGaA, Einbeck, Germany). The pre-breeding populations, compared to breeding lines, were quite heterozygous and less advanced (KWS SAAT SE \& Co. KGaA, personal communication). Currently, limited information on genetic variation for resistance or tolerance to $D$. dipsaci in sugar beet has been published (Kühnhold 2011; Leipertz and Valder 2020). The cvs. BELLADONNA KWS and BERETTA KWS, known to be susceptible and tolerant to the fungal and bacterial infection introduced by $D$. dipsaci in the field, respectively, were used in this study (Leipertz and Valder 2020). The paternal line 'DIT_006' of the cv. BELLADONNA KWS and the paternal line 'DIT_005' of the cv. BERETTA KWS were used as standards for the experiments. 


\section{General methods}

The sugar beet seeds were sown in 200-ml plastic pots filled with a $180-\mathrm{ml}$ non-sterile sieved loess soil: compost mixture $(1 / 1)(\mathrm{v} / \mathrm{v})$. The loess soil originated from Einbeck (Germany). Per pot, three seeds of pre-breeding populations or two seeds of breeding lines were sown to compensate for the partially low sugar beet germination rate. After the emergence of the first plant, all following emerging plants were removed each day to ensure only one seedling per pot remained. Due to the large variation of growth rates among genotypes, nematode inoculation was split into two inoculation time intervals. At 8 and 11 days post-planting (dpp), approx. $1.5 \mathrm{~cm}$ from the centre of the pot, 500 nematodes (of mixed life stages) were inoculated in $500 \mu \mathrm{l}$ into two $1-\mathrm{cm}$ deep holes (diam. $3 \mathrm{~mm}$ ), resulting in $1000 \mathrm{D}$. dipsaci individuals/plant. The plants were regularly watered to maintain a suitable soil moisture allowing nematode movement during the entire experiment. The resistance of the genotypes towards $D$. dipsaci penetration was determined by the number of nematodes in the whole plant at $22 \mathrm{dpp}$. The sugar beet seedlings were removed from the pots at $22 \mathrm{dpp}$, gently washed, transferred to a plastic beaker containing a $0.1 \%$ acid fuchsin/ lactic solution, and boiled twice in a microwave oven for 1 min (Kühnhold et al. 2006). The stained seedlings were then rinsed to remove the staining solution. The total number of nematodes per seedling was counted using a stereomicroscope at 10x magnification after maceration of the whole plant (6500 RPM) in $30 \mathrm{ml}$ tap water using an Ultra Turrax blender (T25 basic/S25 N - 18 G, IKA Labortechnik, Germany). The resistance of the genotypes towards D. dipsaci reproduction was determined by the number of nematodes in the whole plant at 60 post-inoculation (dpi). The sugar beet plants were removed from the pots at 60 dpi, washed, weighed (whole fresh plant), and the whole plants cut into $0.5-\mathrm{cm}$ pieces. Nematodes were extracted from the sliced plant material using Oostenbrink dishes for $24 \mathrm{~h}$ (European and Mediterranean Plant Protection Organization 2013). The number of $D$. dipsaci individuals per sugar beet plant was determined by counting $3 \times$ $1 \mathrm{ml}$ aliquots from $15 \mathrm{ml}$ total volume using an optical microscope at $x 40$ magnification. The effect of the genotypes on the nematode incidence (\%) at the harvest time point (number of plants containing nematodes/number of harvested plants*100) and on the incidence of the symptoms (Fig. 1) (number of swollen plants at $14 \mathrm{dpi} /$ number of germinated plants at $14 \mathrm{dpi} * 100)$ was determined in experiments 2 and 3 . The number of harvested sugar beet at $60 \mathrm{dpi}$ in relation to the number of emerged plants at 22 dpp determined plant survival (\%).

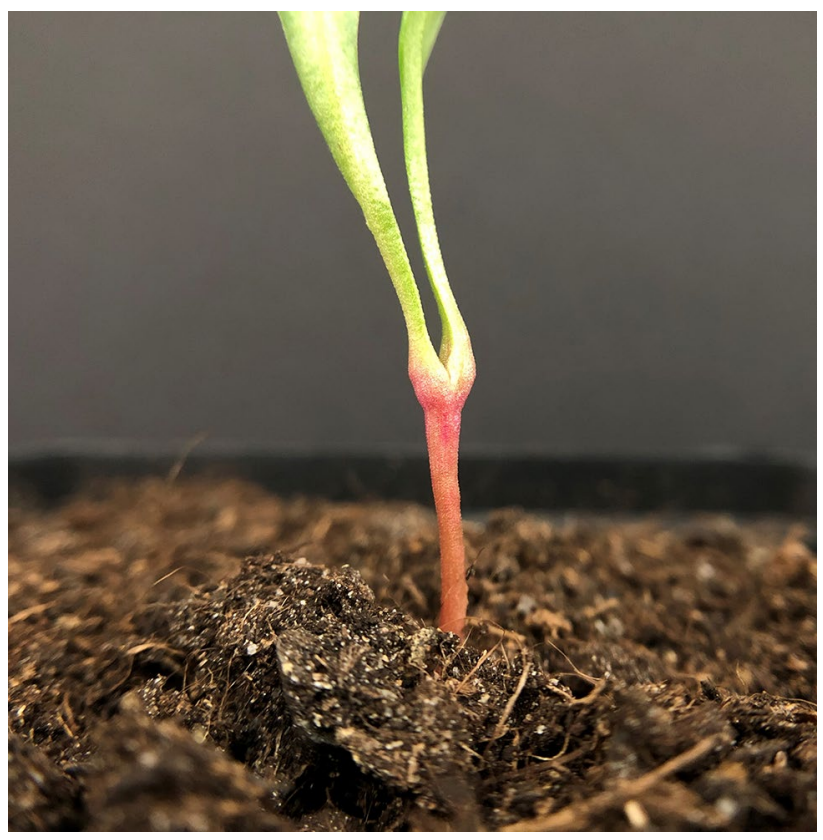

Fig. 1 Ditylenchus dipsaci infected sugar beet seedling at 14 days post-inoculation (dpi) showing swollen leaf-axil

\section{Experiment 1: screening of sugar beet lines for Ditylenchus dipsaci penetration}

To estimate the genetic variation of genotypes belonging to breeding lines (79) or pre-breeding populations (14), they were screened for their response concerning $D$. dipsaci penetration rates. 'DIT_006' was used as the susceptible standard to determine the relative (\%) penetration susceptibility (number of nematodes in inbred line 'DIT_xxx'/number of nematodes in 'DIT_006'*100). The experiments were set up at $15 \mathrm{max} / 8 \mathrm{~min}{ }^{\circ} \mathrm{C}$ temperature range and a photoperiod of $18 / 6 \mathrm{hr}$ day/night and conducted twice in a glasshouse. The investigation of breeding lines and pre-breeding populations was performed with 10 and 15 replicates, respectively.

\section{Experiment 2-effect of sugar beet genotypes on $D$. dipsaci penetration potential}

Genotypes selected for their response after inoculation with D. dipsaci in the first screening experiment were investigated for their potential to reduce penetration rates of this nematode pest. Only the sugar beet genotypes showing the lowest and the highest $D$. dipsaci penetration values in experiment 1 were further investigated in experiment 2 with a greater replication number. The experiment was set up as described above regarding the temperature range and photoperiod and conducted twice in a growth chamber (KBWF 720, Binder $\mathrm{GmbH}$, Germany), with 20 replicates. 


\section{Experiment 3-effect of sugar beet genotypes on $D$. dipsaci reproduction potential}

Genotypes selected for their response after inoculation with $D$. dipsaci in the first screening experiment were investigated for their potential to reduce reproduction of the species. The experiment commenced in a growth chamber (KBWF 720, Binder GmbH, Germany) under the same temperature and photoperiod conditions as indicated above for experiments 1 and 2. For optimal growth of the sugar beets, the plants were transferred, at $22 \mathrm{dpp}$, to a glasshouse where a temperature range of $22 \mathrm{max} / 15 \mathrm{~min}{ }^{\circ} \mathrm{C}$ and a photoperiod of $18 / 6 \mathrm{hr}$ day/night prevailed. The experiment was performed with 10 replicates and conducted twice. For each genotype, $2 \mathrm{x}$ 10 replicates of non-inoculated plants were used as control.

\section{Data analyses}

The investigation of the effect of the breeding lines on the aggressiveness of $D$. dipsaci in experiment 1 was performed in a randomized complete block design. The investigation of pre-breeding populations in experiment 1 and investigations in experiments 2 and 3 were performed in a complete randomized design. In experiment 1, a Friedman rank-sum test was performed to determine the effect of the breeding lines on $D$. dipsaci penetration rate in the whole sugar beet seedlings. The effect of the pre-breeding populations on $D$. dipsaci penetration rate in experiment 1 was determined by using a Kruskal-Wallis rank-sum test. In experiments 2 and 3, problems with normal distribution led to using a
Kruskal-Wallis rank-sum test to determine the effect of the genotype on $D$. dipsaci penetration and reproduction rate, respectively. Dunn's multiple comparison tests were performed as post hoc tests. In experiment 3, the effect of $D$. dipsaci inoculation on the fresh biomass of each beet plant at 60 dpi was determined by performing a Wilcoxon signedrank test to compare data for inoculated and non-inoculated plants. Statistical analyses and figures were performed using the software R.

\section{Results}

\section{Experiment 1: screening of sugar beet lines for Ditylenchus dipsaci penetration}

No significant difference of $D$. dipsaci penetration into sugar beet seedlings was observed among the breeding lines $(P>0.05$, Fig. 2$)$. The average number of nematodes penetrating sugar beet seedling at $22 \mathrm{dpp}$ varied from 7.5 to 105.2 nematodes per plant. The standard 'DIT_006' showed an average of $80.5 \pm 19.1$ nematodes per plant at 22 dpp. 'DIT_119' showed the lowest (10.6\%) and 'DIT_144' the highest (129.2\%) relative susceptibility to $D$. dipsaci penetration. The breeding line 'DIT_005' showed $60.4 \pm 15.3$ nematodes per plant at $22 \mathrm{dpp}$. The pre-breeding populations significantly affected $D$. dipsaci penetration into sugar beet seedlings $(P<0.05$, Fig.3). The pre-breeding populations 'DIT_207' showed the lowest number of nematodes per plant $(12.2 \pm 20.9)$ at $22 \mathrm{dpp}$.

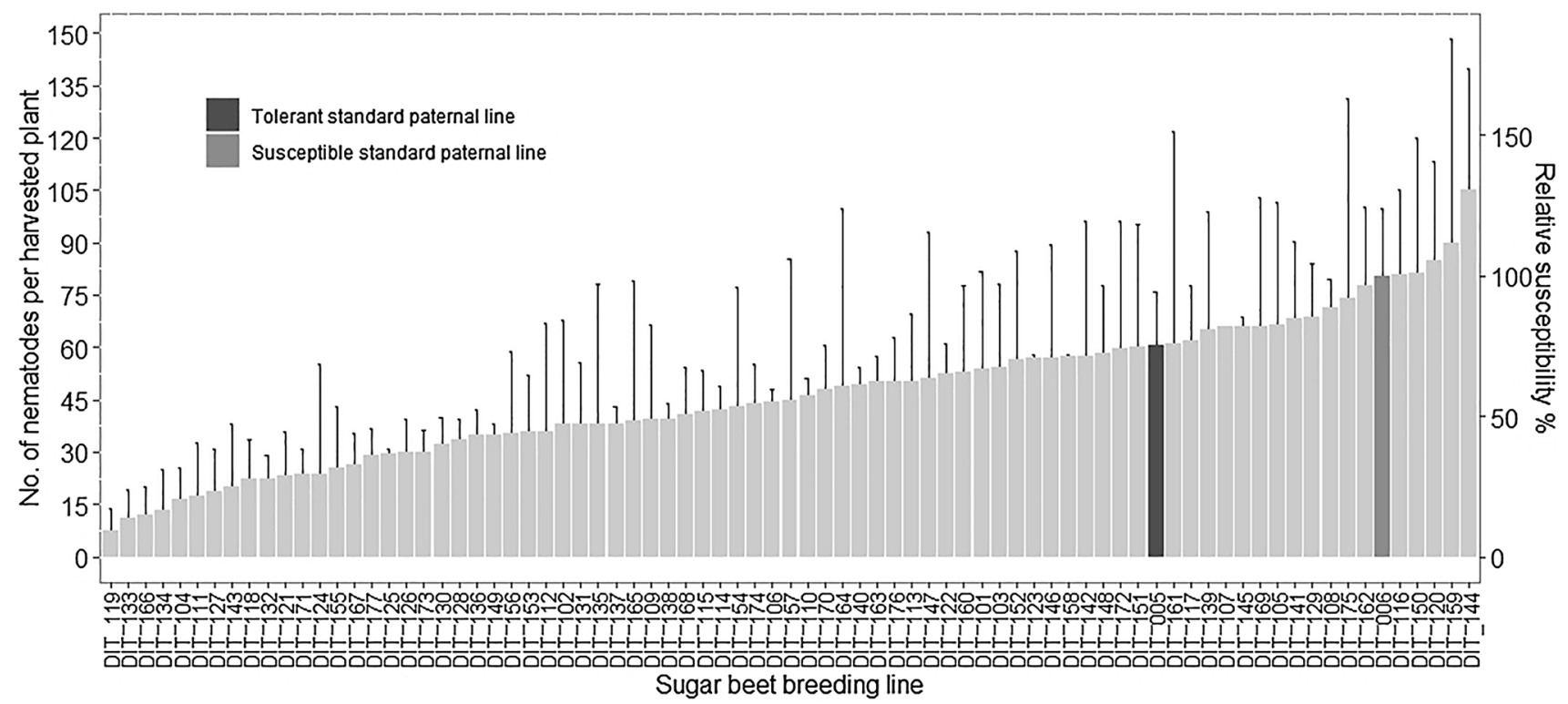

Fig. 2 Effect of sugar beet breeding lines on Ditylenchus dipsaci number per harvested plant at 22 days post-planting (dpp), and their relative susceptibility (\%) to D. dipsaci (average number of nema- todes per plant/average number of nematodes in the inbred line DIT_006) in a glasshouse trial. No significant differences among breeding lines according to Friedman rank-sum test $(n=10)$ 


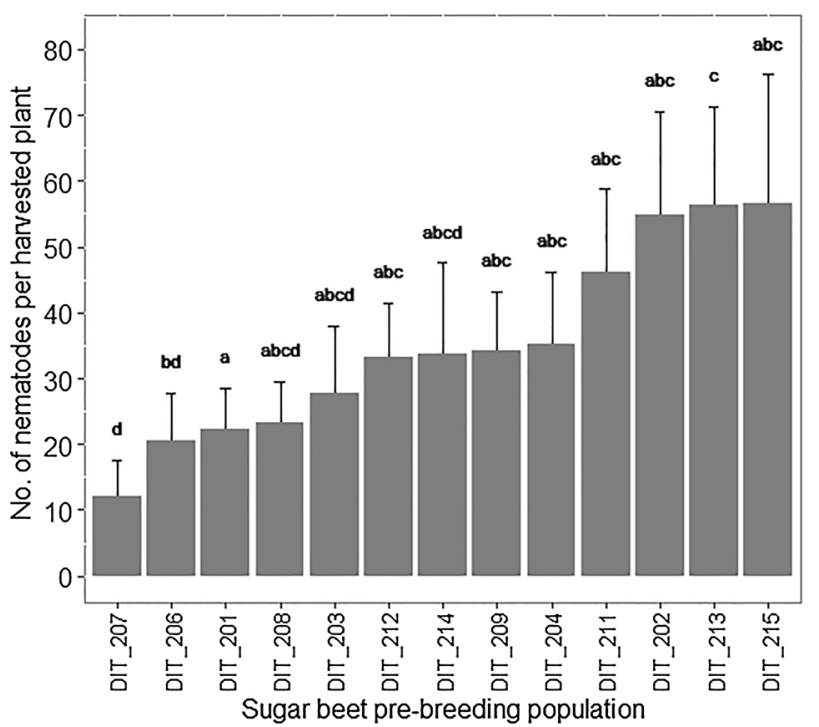

Fig. 3 Effect of sugar beet pre-breeding lines on Ditylenchus dipsaci number per harvested plant at 22 days post-planting (dpp) in a glasshouse trial. Different letters above the bars indicate significant differences between pre-breeding lines at $p<0.05$, according to Dunn's multiple comparison test $(\mathrm{n}=15)$

In contrast, 'DIT_213' contained the highest number of nematodes per plant at $22 \mathrm{dpp}(56.7 \pm 75.6)$.

\section{Experiment 2-Effect of sugar beet genotypes on $D$. dipsaci penetration potential}

In contrast to experiment 1 , the genotypes tested significantly influenced $D$. dipsaci penetration into sugar beet seedlings ( $P \leq 0.0001$, Fig. 4$)$. At $22 \mathrm{dpp}$, the susceptible line 'DIT_006' contained an average of $109 \pm 16.9$ nematodes per plant, significantly higher than 'DIT_207', 'DIT_166', and 'DIT_119' with 11.2 $\pm 2.8,19.2 \pm 5.3$, and $34.4 \pm 8.8$ nematodes per plant, respectively. The pre-breeding population 'DIT_207' did not significantly reduce the number of penetrated nematodes into sugar beet seedling at $22 \mathrm{dpp}$ compared to the pre-breeding population 'DIT_213' (54.1 \pm 18.3$)$. All seedlings of the breeding lines 'DIT_005', 'DIT_006', 'DIT_144', and 'DIT_150' contained nematodes at $14 \mathrm{dpi}$ (Table 1). The breeding line 'DIT_166' showed the lowest incidence, with 74\% seedlings containing $D$. dipsaci individuals. Concerning the incidence of the symptoms at 14 dpi (Table 1), the breeding line 'DIT_119' and the pre-breeding population 'DIT_207' showed the lowest percentage of swollen hypocotyls (13\%). The pre-breeding population 'DIT_213' contained the highest percentage of swollen hypocotyls $(73 \%)$.

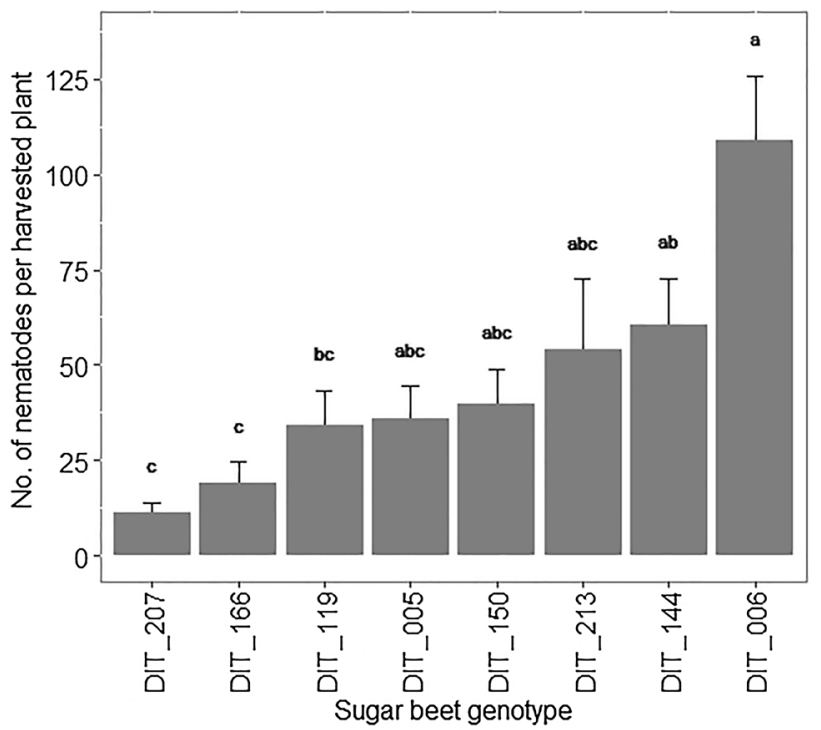

Fig. 4 Effect of sugar beet genotypes on Ditylenchus dipsaci number per harvested plant at 22 days post-planting (dpp) in a growth chamber trial. Different letters above the bars indicate significant differences between genotypes at $p<0.05$, according to Dunn's multiple comparison test $(\mathrm{n}=20)$

\section{Experiment 3-effect of sugar beet genotypes on $D$. dipsaci reproduction potential}

The genotype tested significantly influenced $D$. dipsaci reproduction in sugar beet $(P \leq 0.001$, Fig. 5). 'DIT_207', 'DIT_150', and 'DIT_006' led to the highest $D$. dipsaci reproduction with $6,097 \pm 1,863,8,255 \pm 1,091$, and $8,670 \pm 3,429$ nematodes per harvested plant at $60 \mathrm{dpi}$. The effect of

Table 1 Effect of the genotype on the incidence of the symptoms induced by Ditylenchus dipsaci penetration into sugar beet at 14 days post-inoculation (dpi) (number of swollen plants at $14 \mathrm{dpi} / \mathrm{num}$ ber of germinated plants at $14 \mathrm{dpi}^{*} 100$ ) and on the $D$. dipsaci incidence (number of plants containing nematodes/number of harvested plants*100 at 14 and $60 \mathrm{dpi})$ in experiments $2(\mathrm{n}=20)$ and $3(\mathrm{n}=10)$

\begin{tabular}{|c|c|c|c|c|}
\hline \multirow[t]{2}{*}{ Line } & \multicolumn{2}{|c|}{ Symptoms incidence (\%) } & \multicolumn{2}{|c|}{$\begin{array}{l}\text { D. dipsaci incidence } \\
(\%)\end{array}$} \\
\hline & Experiment 2 & Experiment 3 & $\begin{array}{l}\text { Experiment } \\
2 \text { (14 dpi) }\end{array}$ & $\begin{array}{l}\text { Experi- } \\
\text { ment } 3(60 \\
\text { dpi) }\end{array}$ \\
\hline 'DIT_005' & 70 & 50 & 100 & 100 \\
\hline 'DIT_006' & 33 & 58 & 100 & 100 \\
\hline 'DIT_119' & 13 & 30 & 91 & 100 \\
\hline 'DIT_144' & 30 & 80 & 100 & 100 \\
\hline 'DIT_150' & 40 & 70 & 100 & 100 \\
\hline 'DIT_166' & 30 & 40 & 74 & 89 \\
\hline 'DIT_207' & 13 & 90 & 88 & 100 \\
\hline 'DIT_213' & 73 & 100 & 96 & 100 \\
\hline
\end{tabular}




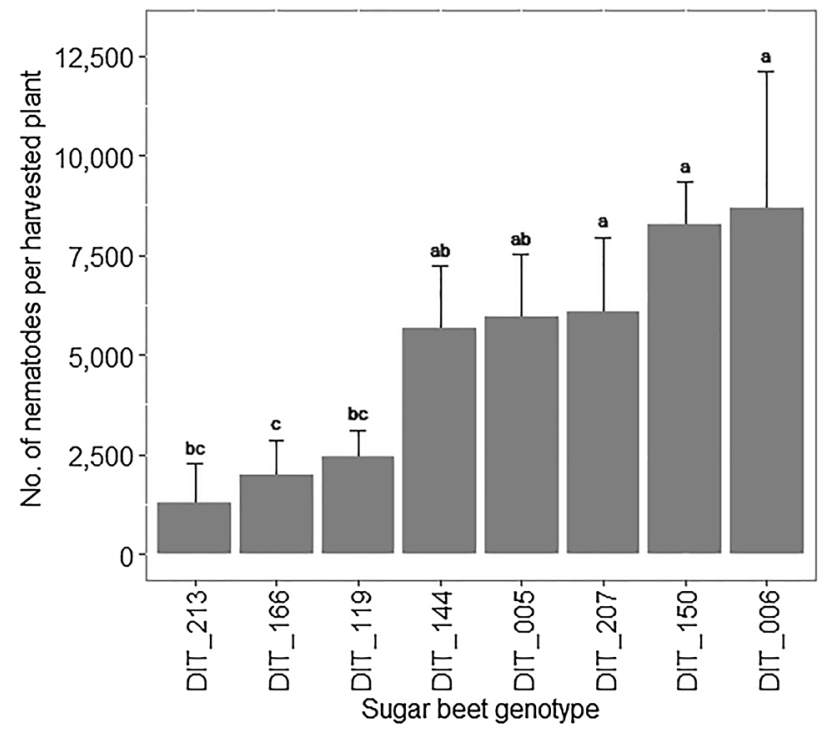

Fig. 5 Effect of sugar beet genotypes on Ditylenchus dipsaci number per harvested plant at 60 days post-inoculation (dpi). Different letters above the bars indicate significant differences between genotypes at $p$ $<0.05$, according to Dunn's multiple comparison test $(\mathrm{n}=10)$

'DIT_207', 'DIT_150', and 'DIT_006' on D. dipsaci reproduction significantly differed from 'DIT_213', 'DIT_166', and 'DIT_119'. At 60 dpi, the number of nematodes per harvested plant was $1,298.5 \pm 985.8,1,978 \pm 895.5$, and $2,437.5 \pm 687.6$ in the genotypes 'DIT_213', 'DIT_166', and 'DIT_119', respectively. The breeding line 'DIT_166' was the only genotype showing plants without nematode at $60 \mathrm{dpi}$ with a nematode incidence of $89 \%$ (Table 1). Concerning the incidence of the symptoms at 14 dpi (Table 1), the breeding lines 'DIT_119' (30\%) and 'DIT_166' (40\%) showed the lowest percentage of swollen hypocotyls. The pre-breeding population 'DIT_213' contained the highest percentage of swollen hypocotyls (100\%). For the genotypes 'DIT_006', 'DIT_144', 'DIT_207', and 'DIT_166', after inoculation with $D$. dipsaci, the fresh plant weight was significantly reduced after 60 days $(P \leq$ 0.05 , Table 2). Whereas, $D$. dipsaci inoculation did not significantly reduce the sugar beet fresh plant weight of 'DIT_005', 'DIT_119', 'DIT_150', and 'DIT_213' compared to the noninoculated plants. The breeding line 'DIT_119' showed the highest survival rate, with $95 \%$ harvestable at 60 dpi (Table 2). In contrast, $25 \%$ of germinated plants of 'DIT_213' were harvestable at $60 \mathrm{dpi}$. All D. dipsaci non-inoculated plants (100\%) survived until harvest (60 dpi).

\section{Discussion}

This study demonstrated the genetic variation of sugar beet genotypes at reducing $D$. dipsaci penetration into seedlings. The high variation among the genotypes is encouraging from
Table 2 Effect of Ditylenchus dipsaci inoculation on the sugar beet fresh weight ( $\mathrm{g}$ ) at 60 days post-inoculation (dpi) and survival (\%) (number of harvested plants at $60 \mathrm{dpi} /$ number of germinated plants at 22 days post-planting) in a glasshouse trial

\begin{tabular}{llll}
\hline Line & \multicolumn{2}{l}{ Plant weight $(\mathrm{g})^{\mathrm{a}}$} & Survival (\%) \\
\cline { 2 - 3 } & Inoculated & Non-inoculated & \\
\hline 'DIT_005' & $7.6( \pm 2.3)$ & $9.3( \pm 1.1)$ & $80( \pm 14.1)$ \\
'DIT_006' & $6.4( \pm 4.3)$ & $12.3( \pm 3.3)^{* *}$ & $60.7( \pm 15.2)$ \\
'DIT_119' & $11.3( \pm 4.2)$ & $13( \pm 4.6)$ & $95( \pm 7.1)$ \\
'DIT_144' & $4.8( \pm 3.4)$ & $10.1( \pm 0.8)^{* *}$ & $50( \pm 28.3)$ \\
'DIT_150' & $8.7( \pm 3.5)$ & $10.3( \pm 3.9)$ & $75( \pm 21.2)$ \\
'DIT_166' & $9.5( \pm 2.8)$ & $12.5( \pm 3.1)^{*}$ & $73.3( \pm 9.4)$ \\
'DIT_207' & $7.5( \pm 3)$ & $12.7( \pm 3.5)^{* *}$ & $75( \pm 21.2)$ \\
'DIT_213' & $9.6( \pm 2.6)$ & $9.3( \pm 3.2)$ & $25( \pm 0)$ \\
\hline
\end{tabular}

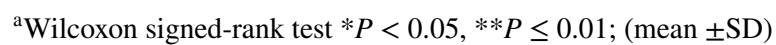

the perspective of finding resistance to $D$. dipsaci penetration. A lower $D$. dipsaci penetration rate in experiment 1 than in experiment 2 suggests a lower inoculation success. Indeed, 'DIT_119' seedlings contained 4.5 times less $D$. dipsaci individuals in experiment 1 than in experiment 2. The low inoculation success in experiment 1 may explain the high variation observed within the genotypes. Despite the lack of significant differences among the breeding lines, some genotypes, such as 'DIT_119' and 'DIT_166', were superior in terms of their low variance of $D$. dipsaci number penetrating sugar beet seedlings. After considering the results from experiment 1 , tolerance to $H$. schachtii does not involve resistance to $D$. dipsaci penetration. Due to crosspollination, the pre-breeding populations consist of a mixture of homozygous and heterozygous individuals (Bos and Caligari 2008), explaining the high variation observed. The second experiment confirms the higher level of resistance of 'DIT_207', 'DIT_119', and 'DIT_166' towards D. dipsaci penetration. In contrast, the susceptible breeding line 'DIT_006' attests to its low resistance to $D$. dipsaci penetration. The second experiment suggests that the increase in repetitions $(n=20)$ significantly improves the probability of observing differences among the genotypes. In the third experiment, nematode reproduction was observed in the eight genotypes tested. However, the number of produced nematodes varied among the genotypes. 'DIT_119' and 'DIT_166' validated their higher resistance level towards $D$. dipsaci infection. Based on the values obtained in the second and third experiments (number of nematodes at $22 \mathrm{dpp}$ and at $60 \mathrm{dpi}$ ), the nematode population in each genotype increased up to 100 -fold, suggesting that the mechanisms responsible for resistance occurred during the penetration. Ditylenchus dipsaci proved to have a rapid population growth (Abolfazl et al. 2017; Kühnhold et al. 2006; Storelli et al. 2020). The few nematodes that penetrated sugar beet 
seedling produced a high number of nematodes at $60 \mathrm{dpi}$. The low $D$. dipsaci number at $60 \mathrm{dpi}$ observed in the prebreeding population 'DIT_213' was not the effect of resistance towards $D$. dipsaci reproduction. The remaining plants of 'DIT_213' presented rotten hypocotyls at harvest. As $D$. dipsaci is an obligate plant parasite (Duncan and Moens 2013), the rotting of its feeding site led the nematodes to leave the plant before the time point of plant harvest. Abolfazl et al. (2017) showed the inability of $D$. dipsaci to reproduce on fungi. The low survival and germination of infected plants compared to the non-infected plants suggest a high sensitivity of the pre-breeding population 'DIT_213' to $D$. dipsaci infection. The earlier emergence of 'DIT_119' may explain the lowest $D$. dipsaci penetration into sugar beet seedlings. Indeed, it has been observed in the present study that 'DIT_119' emerged earlier compared to the other genotypes. The period of susceptibility of sugar beets to $D$. dipsaci penetration occurs at the emergence of the plant (Storelli et al. 2021). The rapid growth of 'DIT_119' may then reduce this period of susceptibility. It may also explain its lowest amount of swollen hypocotyls and its higher survival rate. Nematode penetration occurs later when the seedlings are already better developed to head to swellings of the hypocotyl. Griffith et al. (1997) indeed reported that symptoms initiation might occur before petioles are fully differentiated. A screening of a large-scale population of early emerging sugar beet genotypes to penetration and infection by $D$. dipsaci may help to validate this statement in the future. The absence of swollen hypocotyls allowed 'DIT_119' to grow with well-developed leaves until $60 \mathrm{dpi}$. In contrast, a higher proportion of damaged leaf-axils in the other genotypes did not allow for a proper development of the hypocotyl, which later forms the beet. Similar plant biomass measurements between inoculated and non-inoculated plants suggest a higher tolerance of 'DIT_119' to D. dipsaci at $60 \mathrm{dpi}$ than other genotypes. However, D. dipsaci damages may occur later during the beet storage (Schomaker and Been 2013). The increased amount of nematodes found in the whole plant tissue of 'DIT_119' at 60 dpi suggested no strong resistance towards $D$. dipsaci reproduction. Many non-swollen hypocotyls contained nematodes at 14 and 60 dpi. These results suggest that $D$. dipsaci can survive in plant tissue without exhibiting symptoms (Cook and Evans 1988). However, this statement is not valid for each $D$. dipsaci host plant. Caubel et al. (1994) positively correlated the lack of symptoms with the absence of nematode in red clover tissue. Resistance can be thus determined by characterizing the symptoms on seedlings, which facilitates the screening of a wide range of plant genotypes (Plowright et al. 2002). However, resistance determination based on expressed symptoms does not work on sugar beet interacting with $D$. dipsaci. The presence of a low $D$. dipsaci number is sufficient to trigger abnormal morphogenesis (Griffith et al.
1997). In contrast, a high amount of $D$. dipsaci in sugar beet seedling does not automatically lead to a swollen hypocotyl. Leipertz and Valder (2020) reported tolerance of BERETTA KWS towards the fungal and bacterial infection introduced by $D$. dipsaci in the field. The high susceptibility of 'DIT_005', the paternal line of BERETTA KWS, suggests no direct relation between the resistance of one hybrid component towards $D$. dipsaci development and tolerance of a respective hybrid to the fungal and bacterial infection introduced by $D$. dipsaci. The nematode inoculation success depends on environmental conditions and the viability of the inoculated nematode population (Storelli et al. 2021). This was also demonstrated by the experiments shown here. Thus, nematode aggressiveness towards sugar beet is highly heterogeneous across the experiments and within the cultivars (Kühnhold 2011; Westphal 2013). When evaluating inoculation experiments, a possible inoculation failure must be taken into account in any case. After an inadequate inoculation or if the inoculation fails, the subsequently determined infection level may be low, but the plants are not necessarily resistant (Francis and Luterbacher 2003). Additionally, the existence of a few susceptible plants may bias the resistant pre-breeding population's observation since they were not genetically homogeneous (Scholten et al. 2001). This study did not succeed to find complete resistance in sugar beet genotypes towards $D$. dipsaci penetration or reproduction under glasshouse conditions. However, partial resistance to D. dipsaci penetration was observed in some genotypes, where a proportion of plants was less or not affected (Bovien 1955). The lowest incidence of $D$. dipsaci presence in sugar beet seedlings was observed for the breeding line 'DIT_166' suggesting potential candidates with resistance within this line. The pre-breeding population 'DIT_207', with its particular low heterogeneity and low number of $D$. dipsaci per seedling, is a potential candidate for a source of resistance towards $D$. dipsaci penetration, despite the high incidence and reproduction rate of the nematode. The initial inoculum level used in the experiments was up to 1000-fold higher than an initial natural density occurring in the field at sowing (Storelli et al. 2020). An initial density of $10 \mathrm{D}$. dipsaci individuals per $500 \mathrm{~g}$ soil may cause severe damage to onions. The damage was nearly $100 \%$ when the initial density of $25 \mathrm{D}$. dipsaci individuals per $500 \mathrm{~g}$ soil was reached (Seinhorst 1956). With an increasing initial density of $H$. schachtii, the yield ofresistant sugar beet cultivars decreased (Heijbroek et al. 2002). Further trials under field conditions and at lower nematode density may determine the investigated genotypes' real resistance potential. Khanam et al. (2018) reported a similar penetration of $D$. angustus in the resistant and susceptible rice cultivars, suggesting that host attraction is not linked to resistance. However, D. dipsaci damages to sugar beet seedlings encourage resistance development through penetration (Cottage and Urwin 2013). 
Therefore, screening a large number of pre-breeding populations is recommended as they represent a source of genes for resistance (Tanksley and McCouch 1997). Much of the available germplasm resources remain to be characterized for resistance to nematodes (Starr et al. 2002). Due to the lack of resistant cultivars, high-yielding cultivars, tolerant to the fungal and bacterial infection introduced by $D$. dipsaci, are now the only measure to avoid economic damage. As different fungal and bacterial organisms are introduced by $D$. dipsaci, a case-by-case study is recommended to grow specific cultivars tolerant to the pathogen introduced by the nematode. In a field infested with $R$. solani, the use of $R$. solani resistant cultivars will prevent high yield reduction (Hillnhütter et al. 2011). The use of resistant crops, such as oat, in the rotation to reduce the nematode population has to be further investigated. Thus, tolerant sugar beet cultivars and resistant crops may probably help to maintain a sustainable sugar production in $D$. dipsaci infested fields while resistant cultivars are urgently needed for growers.

Acknowledgements The authors thank the seed company KWS SAAT SE \& Co. KGaA (D), the sugar factory Schweizer Zucker AG $(\mathrm{CH})$, and the Bern University of Applied Sciences $(\mathrm{CH})$ for their financial support. We would like to further acknowledge the working group of Nematology at Agroscope $(\mathrm{CH})$ for providing the $D$. dipsaci population.

Funding Open Access funding provided by Berner Fachhochschule BFH. This study was funded by KWS SAAT SE \& Co. KGaA, Grimsehlstrasse 31, 37574 Einbeck, Germany; School of Agricultural, Forest and Food Sciences HAFL, Bern University of Applied Sciences BFH, Länggasse 85, 3052 Zollikofen, Switzerland; and Schweizer Zucker AG, Radelfingenstrasse 30, 3270 Aarberg, Switzerland.

Availability of data and material The data that support the findings of this study are available from the corresponding author.

\section{Declaration}

\section{Conflicts of interest None.}

Consent for publication All authors give their consent for the publication of the manuscript in the Journal of Plant Diseases and Pests.

Open Access This article is licensed under a Creative Commons Attribution 4.0 International License, which permits use, sharing, adaptation, distribution and reproduction in any medium or format, as long as you give appropriate credit to the original author(s) and the source, provide a link to the Creative Commons licence, and indicate if changes were made. The images or other third party material in this article are included in the article's Creative Commons licence, unless indicated otherwise in a credit line to the material. If material is not included in the article's Creative Commons licence and your intended use is not permitted by statutory regulation or exceeds the permitted use, you will need to obtain permission directly from the copyright holder. To view a copy of this licence, visit http://creativecommons.org/licenses/by/4.0/.

\section{References}

Abolfazl H, Mario T, Robert HG (2017) Monoxenic rearing of Ditylenchus weischeri and $D$. dipsaci and microplot examination of the host suitability of yellow pea to D. weischeri. Plant Protect Sci 53:254-264. https://doi.org/10.17221/158/2016-PPS

Blake CD (1962) The etiology of tulip-root disease in susceptible and in resistant varieties of oats infested by the stem nematode, Ditylenchus dipsaci (Kühn) Filipjev. Ann Appl Biol 50:703-712. https://doi.org/10.1111/j.1744-7348.1962.tb06071.x

Blok VC, Tylka GL, Smiley RW, de Jong WS, Daub M (2018) Resistance breeding. In: Perry RN, Moens M, Jones JT (eds) Cyst nematodes. CAB International, Oxfordshire, pp 174-214

Bos I, Caligari PDS (2008) Selection methods in plant breeding, 2nd edn. Springer, Dordrecht

Bovien P (1955) Host specificity and resistance in plant nematodes. Ann Appl Biol 42:382-390. https://doi.org/10.1111/j.1744-7348. 1955.tb02443.x

Caubel G, Chatot F, Mousset-Declas C (1994) Résistance variétale du trèfle violet au nématode des tiges Ditylenchus dipsaci. Fourrages 138:165-173

Cook R, Evans DR (1988) Observations on resistance in white clover (Trifolium repens L.) to the stem nematode (Ditylenchus dipsaci (Kühn) Filipjev). J Agric Sci 110:145-154. https://doi.org/10. 1017/S0021859600079788

Cottage A, Urwin P (2013) Genetic engineering for resistance. In: Perry RN, Moens M (eds) plant nematology, 2nd edn. CABI, Ghent, Belgium, pp 437-458

Dewar AM, Cook DA (2006) Pests. In: Draycott AP (ed) Sugar beet. Blackwell Pub, Oxford, pp 316-358

Duncan LW, Moens M (2013) Migratory endoparasitic nematodes. In: Perry RN, Moens M (eds) Plant Nematology, 2nd edn. CABI, Ghent, pp 144-178

European and Mediterranean Plant Protection Organization (2013) PM 7/119 (1) Nematode extraction. EPPO Bull 43:471-495. https:// doi.org/10.1111/epp. 12077

Francis SA, Luterbacher MC (2003) Identification and exploitation of novel disease resistance genes in sugar beet. Pest Manag Sci 59:225-230. https://doi.org/10.1002/ps.569

Golden AM (1959) Susceptibility of several Beta species to the sugar beet nematode (Heterodera schachtii) and root knot nematodes (Meloidogyne spp.). J ASSBT 10:444-447. https://doi.org/10. 5274/jsbr.10.5.441

Griffin GD (1983) The Interrelationship of Heterodera schachtii and Ditylenchus dipsaci on sugarbeet. J Nematol 15:426-432

Griffith GS, Cook R, Mizen KA (1997) Ditylenchus dipsaci Infestation of Trifolium repens. II dynamics of Infestation Development. J Nematol 29:356-369

Griffiths DJ, Holden JHW, Jones JM (1957) Investigations on resistance of oats to stem eelworm, Ditylenchus dipsaci Kühn. Ann Appl Biol 45:709-720. https://doi.org/10.1111/j.1744-7348.1957. tb00415.x

Heijbroek W, Munning RG, Swaaij van ACPM (2002) The effect of different levels of beet cyst nematodes (heterodera schachtii) and beet necrotic yellow vein virus (bnyvv) on single and double resistant sugar beet cultivars. Eur J Plant Pathol 108:735-744. https://doi.org/10.1023/A:1020874511047

Hillnhütter C, Albersmeier A, Berdugo CA, Sikora RA (2011) Synergistic damage by interactions between Ditylenchus dipsaci and Rhizoctonia solani (AG 2-2IIIB) on sugar beet. J Plant Dis Prot 118:127-133. https://doi.org/10.1007/BF03356392

Jones JT, Haegeman A, Danchin EGJ, Gaur HS, Helder J, Jones MGK, Kikuchi T, Manzanilla-López R, Palomares-Rius JE, Wesemael WML, Perry RN (2013) Top 10 plant-parasitic nematodes in 
molecular plant pathology. Mol Plant Pathol 14:946-961. https:// doi.org/10.1111/mpp.12057

Khanam S, Bauters L, Singh RR, Verbeek R, Haeck A, Sultan SMD, Demeestere K, Kyndt T, Gheysen G (2018) Mechanisms of resistance in the rice cultivar Manikpukha to the rice stem nematode Ditylenchus angustus. Mol Plant Pathol 19:1391-1402. https:// doi.org/10.1111/mpp. 12622

Kühn J (1857) Ueber das Vorkommen von Anguillulen in erkrankten Blüthenköpfen von Dipsacus fullonum. In: L. Zeitschrift für wissenschaftliche Zoologie 9, pp 129-137

Kühnhold V, Kiewnick S, Sikora RA (2006) Development of an in vivo bioassay to identify sugar beet resistance to the stem nematode Ditylenchus dipsaci. Nematology 8:641-645. https://doi.org/10. $1163 / 156854106778877875$

Kühnhold V (2011) Investigation on host-parasite interaction between the stem nematode Ditylenchus dipsaci and sugar beet Beta vulgaris and their importance for development of alternative integrated management strategies. Dissertation, Rheinischen Friedrich-Wilhelms-Universität

Leclerq D, Caubel G (1991) Résistance variétale de la luzerne au nématode des tiges Ditylenchus dipsaci (Kühn) Filipjev; test d'évaluation et application en sélectionRésistance variétale de la luzerne au nématode des tiges Ditylenchus dipsaci (Kühn) Filipjev; test d'évaluation et application en sélection. Agronomie 11:603-612. https://doi.org/10.1051/agro:19910708

Leipertz H (2007) Variationzwischen Zuckerrübensorten und stämmen auf Befall mit Ditylenchus dipsaci. In: Deutschen Phytomedizinischen Gesellschaft (ed) Arbeitskreis Nematologie: Symposium in March 2007, pp 187-188

Leipertz H, Valder S (2020) Variation between sugar beet cultivars and strains on damages caused by Ditylenchus dipsaci: Trial records 2019. Euskirchen

McDaniel ME, Barr AR (1994) Register of Australian winter cereal cultivars Avena sativa (oats) cv Bettong Aust. Aust J Exp Agric 34:701

Plowright RA, Caubel G, Mizen KA (2002) Ditylenchus Species. In: Starr JL, Cook R, Bridge J (eds) Plant resistance to parasitic nematodes. CABI, Wallingford, pp 107-139

Roberts PA (2002) Concepts and Consequences of Resistance. In: Starr JL, Cook R, Bridge J (eds) Plant resistance to parasitic nematodes. CABI, Wallingford, pp 23-41

Savitsky H (1975) Hybridization between Beta vulgaris and B. procumbens and transmission of nematode (Heterodera schachtii) resistance to sugarbeet. Can J Genet Cytol 17:197-209. https://doi.org/ 10.1139/g75-027

Scholten, EO Panella, W Lee, DE Bock, SM Theo, Lange W (2001) A greenhouse test for screening sugar beet (beta vulgaris) for resistance to Rhizoctonia Solani. Eur J Plant Pathol. 107(161):166

Schomaker CH, Been TH (2013) Plant growth and population dynamics. In: Perry RN, Moens M (eds) Plant Nematology, 2nd edn. CABI, Ghent, pp 301-330
Seinhorst JW (1956) Population studies on stem eelworms. Nematology 1:159-164. https://doi.org/10.1163/187529256X00555

Stanton JM, Fisher JM, Britton R (1984) Resistance of cultivars of Avena sativa to, and host range of, an oat-attacking race of Ditylenchus dipsaci in South Australia. Aust J Exp Agric 24:267. https://doi.org/10.1071/EA9840267

Starr JL, Bridge J, Cook R (2002) Resistance to plant-parasitic nematodes: history, current use and future potential. In: Starr JL, Cook $\mathrm{R}$, Bridge J (eds) Plant resistance to parasitic nematodes. CABI, Wallingford, pp 1-22

Starr JL, McDonald AH, Claudius-Cole AO (2013) Nematode resistance in Crops. In: Perry RN, Moens M (eds) Plant Nematology, 2nd edn. CABI, Ghent, pp 411-436

Storelli A, Keiser A, Eder R, Jenni S, Kiewnick S (2020) Evaluation of fluopyram for the control of Ditylenchus dipsaci in sugar beet. J Nematol 52(1):10. https://doi.org/10.21307/jofnem-2020-071

Storelli A, Keiser A, Kiewnick S, Daub M, Mahlein A-K, Beyer W, Schumann M (2021) Development of a new in vivo protocol through soil inoculation to investigate sugar beet resistance towards Ditylenchus dipsaci penetration. Nematology 0:1-10. https://doi.org/10.1163/15685411-bja10069

Subbotin SA, Madani M, Krall E, Sturhan D, Moens M (2005) Molecular diagnostics, taxonomy, and phylogeny of the stem nematode ditylenchus dipsaci species complex based on the sequences of the internal transcribed spacer-rdna. Phytopathology 95:1308-1315. https://doi.org/10.1094/PHYTO-95-1308

Tanksley SD, McCouch SR (1997) Seed banks and molecular maps: unlocking genetic potential from the wild. Science 277:10631066. https://doi.org/10.1126/science.277.5329.1063

Vrain TC (1987) Effect of Ditylenchus dipsaci and Pratylenchus penetrans on Verticillium Wilt of Alfalfa. J Nematol 19:379-383

Westphal A (2013) Vertical Distribution of Heterodera schachtii under susceptible, resistant, or tolerant sugar beet cultivars. Plant Dis 97:101-106. https://doi.org/10.1094/PDIS-05-12-0476-RE

Whitehead AG (1992) Sources of resistance to stem nematode, Ditylenchus dipsaci (Kühn) Filipjev, in species of Medicago and Trifolium. Ann Appl Biol 120:73-81. https://doi.org/10.1111/j.17447348.1992.tb03405.x

Yavuzaslanoglu E (2019) Resistance and tolerance of commercial onion cultivars to stem and bulb nematode Ditylenchus dipsaci. J Agric Sci 25:409-416. https://doi.org/10.15832/ankutbd.440179

Publisher's Note Springer Nature remains neutral with regard to jurisdictional claims in published maps and institutional affiliations. 